\title{
IDENTIFICATION AND ISOLATION OF DOMINANT BACTERIA IN TRADITIONAL ISFAHAN CHEESE AND DETERMINATION IF EFFECTIVE COMPOUNDS IN FLAVOR
}

\author{
Farahnaz Karbasiun $^{* 1}$, Hashem Nayeri ${ }^{2,}$ Sedigheh Mehrabian ${ }^{1}$, Mehrnoosh Mirmoghtadayi $^{3}$ \\ Address (es): \\ ${ }^{1}$ Islamic Azad University, North Tehran Branch, Faculty of Basic Sciences, Department of Microbiology, Tehran, Iran,09134082556. \\ ${ }^{2}$ Islamic Azad Universities, Falavarjan Branch, Department of Biochemistry, Isfahan, Iran. \\ ${ }^{3}$ Islamic Azad University Science and Research Branch, Department Biophysics, Tehran, Iran.
}

*Corresponding author: Farahnazkarbasiun@yahoo.com

https://doi.org/10.36547/be.278

\section{ABSTRACT}

Cheese production by native starter cultures instead of commercial ones is beneficial in respect of higher quality, nutrient content, immunogenicity and having beneficial microorganism. The objective of the presented study was molecular identifying of microorganism and exploring its active ingredients in native cheese. MRS and M17 media were used to culture bacteria in 15,37 and $45^{\circ} \mathrm{c}$ for 24,48 and 72 hours and then morphologic and biochemical tests were used to identifying the species. Predominant species were detected using $16 \mathrm{~S}$ rRNA and gene sequencing. Active ingredients and fatty acid profile was studied by GC lactobacili, lactococci and enterococci were identified as the predominant bacteria. Acid palmitic had the highest concentration among the saturated fatty acid, with $42.47 \%$, and acid meristic and acid lauric acid were next with the $13.22 \%$ and $3.9 \%$ concentration respectively, among the unsaturated fatty acids.

Keywords: acid lactic bacteria, fatty acid profile, native starter, Gas chromatography

\section{INTRODUCTION}

Milk is the first and the most important source of nutrition for many mammals before they are able to digest other types of food. It contains many other nutrients including protein, carbohydrates, amino acids and lactose. (Haytowitz et al., 2018). Moreover, Milk is known as one of the richest places of growth of lactic acid bacteria (LAB) (Delavenne et al., 2012; Wouters et al., 2002). Lactic acid bacteria (LAB) are a group of Gram-positive, anaerobic or facultative aerobic, non-sporulating, cocci or rods, and lactic acid is one of the main products of the carbohydrates (Elyass et al. 2017; Hayek et al., 2019). Lactic acid bacteria are the main part of bacteria in desirable food fermentations. They play an essential role in the production of all dairy products and are involved in the production of many other fermented foods. According to the end product of glucose fermentation Lactic acid bacteria include two groups, Homofermenters or Heterofermenters. The Homofermenters produce lactic acid as the main product of fermentation of glucose. The Heterofermenters produce lactic acid, carbon dioxide, acetic acid, and ethanol from the fermentation of glucose. According to (Sharma et al., 2020; Steele et al., 2013) LAB asset has many features, their fermentative ability, improves the digestibility of fermented dairy products, transform lactose, increasing food safety and healthy, improving organoleptic attributes, enriching nutrients. Some of the LAB species have the main role in the ripening process of cheese (Vázquez-Velázquez et al., 2018; Duan et al., 2008; Weinberg et al., 2007) as well as their preservation. They also used to improve the quality of the taste, texture, aroma, flavor, and viscosity in the manufacture of dairy products (Ghalouni et al., 2018; Marcelino et al., 2013) . The objective of the study was to isolate and identify naturally occurring lactic acid bacteria from traditional cheese in Isfahan in center of Iran.

Fermentation by lactic acid bacteria (LAB) is a reasonable and effective food preservation technique and according to the above reasons can use in many processed industrially or by traditional techniques. LAB has useful usage in cheese processing.

Traditional raw-milk cheeses are highly valued for their flavors (Chen et al., 2018), while in pasteurization many flavors eliminate and nutritional Value decrease; while they are opposite of food standards and the food industry looks for a better product to improve human health (Sriphochanart et al., 2010). Nowadays, we need to change older methods, in addition, protect of positive properties of products. Scientists looking for new kinds of LAB starter -cultures in order to increase microbial safety, increased resistance, technological, nutritional, more organoleptic, health advantages, and probiotic properties (Aymerich et al., 2005).

\section{MATERIAL AND METHODS}

\section{Sample collection}

The study was conducted from spring 2015 to isolate and identify the naturally occurring lactic acid bacteria from local cheese. The sample was collected using a sterilized sample bottle and brought to the laboratory with an icebox for microbiological investigation. The sample was kept in a refrigerator (around $4^{\circ} \mathrm{C}$ ) till the analysis begins.

\section{Isolation of lactic acid bacteria}

For isolation of lactic acid bacteria, 10 milliliters of cheese sample was homogenized with sterilized peptone physiological saline solution (1\% peptone (Oxoid), $0.9 \% \mathrm{NaCl})$ for about 1-3 minutes aseptically. Appropriate serial dilution $\left(10^{-1}\right.$ to $\left.10^{-6}\right)$ was prepared. A volume of 0.1 milliliters of appropriate dilutions was spread plated on MRS (OXOID) agar media. Then the plates were incubated for 48hours in an anaerobic jar at 32oC. Typical LAB characteristics colonies were randomly picked up and purify by streaking two or three times on fresh MRS agar plates followed by macroscopic and microscopic examinations. The colonies displaying the general characteristics of lactic acid bacteria were chosen from each plate for the physiological and biochemical tests.

\section{Identification of Lactic Acid Bacteria}

To the Genus Level For the selection of isolated bacteria, overnight cultures of each isolate in MRS broth (Oxoid) were used. All isolates were initially tested for catalase enzyme, motility, and gram reaction. Identification of LAB was done based on morphology, physiology, and biochemical characteristic (Ghalouni et al., 2018; Karakas-Sen et al., 2018). These preliminary tests make it possible to classify the isolates into genus on the basis of characteristics and tests of identification mentioned by Harrigan and MacCance.

\section{Molecular identification}

Pure bacterial isolates were further tested for cell morphology, motility, gram reaction, catalase production, acid production from glucose, and growth at $30 \mathrm{C}$, $37 \mathrm{C}$, and $42 \mathrm{C}$ according to the methods described by Jason Chen Kok Ho, Lim Yin Sze (Ho et al., 2018). Cell morphology of cocci or rod-shaped, grampositive, catalase-negative, non-motile, and isolates with characteristic was considered as lactic acid bacteria. Isolated lactic acid bacteria were tested for fermentation of Glucose, Lactose, Xylose, Sucrose, Arabinose, Galactose, Trehalose, and Sorbitol. All LAB strains were characterized and identified to the genus level according to Bergey's Manual of Determinative Bacteriology (Abdullah et al., 2010).

Total genomic DNA of all isolates was extracted from overnight cultures by using a previously reported method.

For each strain, the purified DNA was used as a template for 16S rRNA gene amplification on the automatic thermal cycler (PTC200, MJ Research, and Waltham, MA). The primers of the 16S rRNA gene were, 27F (5'AGAGTTTGATCCTGG CTCAG-3) and

1492R (5'-GGTTACCTTGTTACGACTT-3).

The reaction mixtures and PCR amplifying procedure was described in the previous study. the sample contained $1 \times$ Taq buffer (TaKaRa Bio Inc., Shiga, Japan), $1.5 \mathrm{mM} \mathrm{MgCl} 2,0.2 \mu \mathrm{M}$ of each dNTP, 10 pmol of each primer, $10 \mathrm{ng}$ of 
template bacterial DNA, and 1.0 U of Ex TaqTM polymerase (TaKaRa Bio Inc.). The reaction conditions were as follows: $94^{\circ} \mathrm{C}$ for $5 \mathrm{~min}, 94^{\circ} \mathrm{C}$ for $1 \mathrm{~min}, 55^{\circ} \mathrm{C}$ for $1 \mathrm{~min}, 72^{\circ} \mathrm{C}$ for $2 \mathrm{~min}, 30 \mathrm{cycles}$, and then $72^{\circ} \mathrm{C}$ for $10 \mathrm{~min}$. The sequencing of $16 \mathrm{~S}$ rRNA gene performed in Macro gene Corporation of northern Korea. The sequences were determined using the BLAST algorithm and were submitted to the National Center for Biotechnology Information (Wang et al., 2015).

\section{Fat extraction}

Fat extraction from cheese, conversely, was performed according to the modified Folch's technique.

The Folch method is the most well-known fatty acid extraction method proposed by Jordi Folch and the most reliable method for the quantitative extraction of lipids (Liu et al., 2014). A mixture of chloroform and methanol at a ratio of 2:1 $(\mathrm{v} / \mathrm{v})$ was used as the extraction solvent, and the final volume must be 20 times the $1 \mathrm{~g}$ sample. After that, water or a salt solution was added to cause the phase separation. The lower phase was used in analyzing fatty acids (Fernandez et al., 2011).

\section{GC_MS (Gas Chromatography)}

Fatty acid methyl esters were detected using a GC_MS Saturn 2100T (Agilent $6890 \mathrm{~N}$, USA) capillary column (50 m length, $0.25 \mathrm{~mm}$ i.d, $0.20 \mu \mathrm{m}$ film thickness). Split injection (1 $\mu \mathrm{L}$ ) was adopted (ratio 1:50) and helium was used as a carrier gas at a flow rate of $1.2 \mathrm{~mL} / \mathrm{min}$. The oven temperature was held at 50 ${ }^{\circ} \mathrm{C}$ for $5 \mathrm{~min}$, programmed to $160{ }^{\circ} \mathrm{C}$ at a rate of $10{ }^{\circ} \mathrm{C} / \mathrm{min}$, held at $160{ }^{\circ} \mathrm{C}$ for 10 min, programmed to $180{ }^{\circ} \mathrm{C}$ at $0.3{ }^{\circ} \mathrm{C} / \mathrm{min}$, held to $180{ }^{\circ} \mathrm{C}$ for $5 \mathrm{~min}$, and then increased to $240{ }^{\circ} \mathrm{C}$ at $20{ }^{\circ} \mathrm{C} / \mathrm{min}$, and held at $240{ }^{\circ} \mathrm{C}$ for $10 \mathrm{~min}$. The transfer line was held at $240{ }^{\circ} \mathrm{C}$ and the mass spectroscopy source at $200{ }^{\circ} \mathrm{C}$. Acquisition was performed in electron ionization mode $(70 \mathrm{eV})$ at $0.4 \mathrm{scan} / \mathrm{s}$, and the mass range used was $10-400 \mathrm{~m} / \mathrm{z}$. The identification of the compound was made by using the NIST library (National Institute of Standards and Technology-NIST,
Gaithersburg, MD, USA), the MS data of literature, and when available, the injection of authentic standards. The fatty acid composition was expressed as $\mathrm{g} / 100 \mathrm{~g}$ of total fatty acids of cheese.

\section{RESULTS AND DISCUSSION}

The main aim of this study was identification and isolation the dominant flora of traditional Isfahan cheese.

Count of colony in 1 gr of Traditional cheese was about $7.5 \times 10^{6}$.

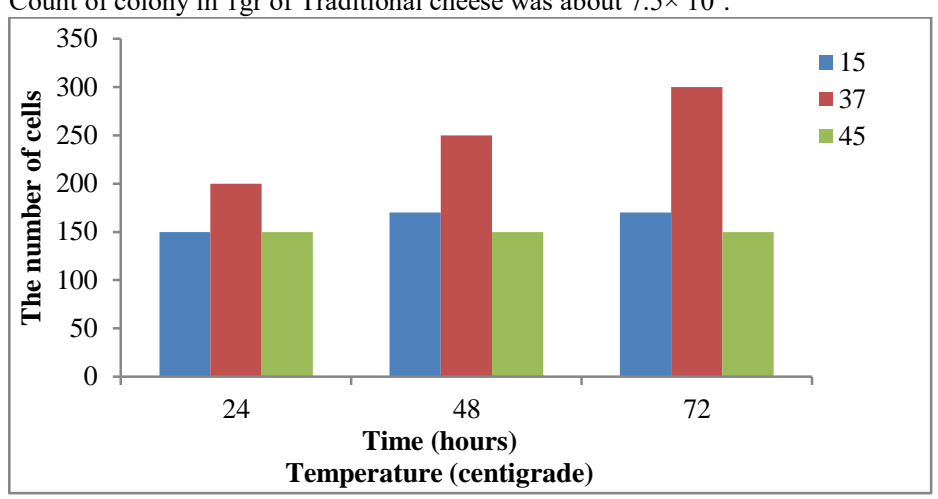

The figure, the number of cells and Grow at 15,37 and $45^{\circ} \mathrm{C}(1-1)$

\section{Identification and Isolation:}

Four isolates were gram negative and catalase positive which are not the characteristics of LAB.

The table (1-1) Identification of Isolate by Grow at aerobic Condition, Morphology, Temperature growth at $15^{\circ} \mathrm{C}$, Temperature growth at $45{ }^{\circ} \mathrm{C}$, Fermentation of Glucose, Culture, Temperature of isolation, Gram Dye, Catalase test, Oxidase test

\begin{tabular}{|c|c|c|c|c|c|c|c|c|c|c|}
\hline Species & $\begin{array}{c}\text { Oxidase } \\
\text { Test }\end{array}$ & $\begin{array}{c}\text { Catalase } \\
\text { test }\end{array}$ & $\begin{array}{l}\text { Gram } \\
\text { Dye }\end{array}$ & $\begin{array}{c}\text { Temperature of } \\
\text { isolation }\end{array}$ & Culture & $\begin{array}{c}\text { Fermentation } \\
\text { of Glucose }\end{array}$ & $\begin{array}{c}\text { Temperature } \\
\text { growth at } 45 \\
{ }^{\circ} \mathrm{C}\end{array}$ & $\begin{array}{c}\text { Temperature } \\
\text { growth at } 15 \\
{ }^{\circ} \mathrm{C}\end{array}$ & Morphology & $\begin{array}{c}\text { Grow at } \\
\text { aerobic } \\
\text { Condition }\end{array}$ \\
\hline Lactobacillus agilis & - & - & + & 37 & M17 & + & - & - & Bacilii & + \\
\hline Lactobacillus plantarum & - & - & + & 37 & MRS & + & - & - & Bacilii & + \\
\hline Lactobacillus paracasei & - & - & + & 37 & MRS & + & - & + & Bacilii & + \\
\hline Lactobacillus salivarius & - & - & + & 37 & MRS & + & - & - & Bacilii & + \\
\hline Streptococcus thermophilus & - & - & + & 37 & M17 & - & + & - & Cocci & + \\
\hline Streptococcus oralis & - & - & + & 37 & MRS & - & - & - & Cocci & + \\
\hline Lactococcus lactis & - & - & + & 37 & MRS & - & - & - & Cocci & + \\
\hline Enterococcus faecalis & - & - & + & 45 & M17 & - & + & + & Cocci & + \\
\hline Enterococcus faecium & - & - & + & 45 & M17 & - & + & + & Cocci & + \\
\hline
\end{tabular}

The table (1-2) Identification of dominant Bacteria in two cultures (MRS and M17)

\begin{tabular}{lccccc}
\hline Species & M17+van & M 17 & MRS+van & MRS & Total \\
\hline Enterococcus & - & 1 & - & 6 & 6 \\
Lactococcus & - & 1 & - & 2 & 3 \\
Lactobacillus & - & 3 & - & - & 3 \\
Pediococcus & - & - & - & - & - \\
\hline
\end{tabular}

The table (1-3), Identification of Enterococcus by five main tests

\begin{tabular}{lccccc}
\hline Species & Gelatinase & Citrate & SIM & $\begin{array}{c}\text { Bile_esc } \\
\text { ulin } \\
(4 \%)\end{array}$ & $\begin{array}{c}\text { NACL } \\
(6.5 \%)\end{array}$ \\
\hline Enterococcusfaecalis & + & + & + & + & + \\
Enterococcusfaecium & + & + & + & + & + \\
\hline
\end{tabular}

Thermophilic starters such as Salivarius subsp, Lb. lactis, Lactobacillus helveticus, Lb. delbrueckii, Lb. casei, Strep, and Bulgaricus .Thermophilic is used in the production of cheeses like Parmesan and Emmental where a higher incubation temperature is employed.

The effects of starter organisms in the cheese process are biotic and intricate. the main function is the fermentation of the sugar lactose to lactic acid. This and the resulting decrease in $\mathrm{pH}$ contribute to the shelf-life and safety of the cheese and give a sharp, fresh flavor to the curd (Acharya et al., 2004). 
The table (1-4) Fermentation of 9 sugars to identification Species

\begin{tabular}{|c|c|c|c|c|c|c|c|c|c|}
\hline Species & Glucose & Lactose & ribose & arabinose & xylose & sacarose & galactose & trehalose & sorbitol \\
\hline Lactobacillus agilis & + & + & + & - & - & + & + & + & - \\
\hline Lactobacillus plantarum & + & + & + & + & + & + & + & + & + \\
\hline Lactobacillus paracasei & + & + & + & - & - & + & + & + & - \\
\hline Lactobacillus salivarius & + & + & + & - & - & + & + & + & - \\
\hline Streptococcus thermophiles & + & + & - & $*$ & $*$ & $*$ & + & + & - \\
\hline Streptococcus oralis & + & + & + & - & - & $*$ & + & + & - \\
\hline Lactococcus lactis & + & + & + & $*$ & $*$ & $*$ & + & $*$ & - \\
\hline Enterococcus faecalis & + & + & $*$ & - & - & + & + & $*$ & - \\
\hline Enterococcus faecium & + & + & $*$ & + & - & + & + & + & - \\
\hline
\end{tabular}

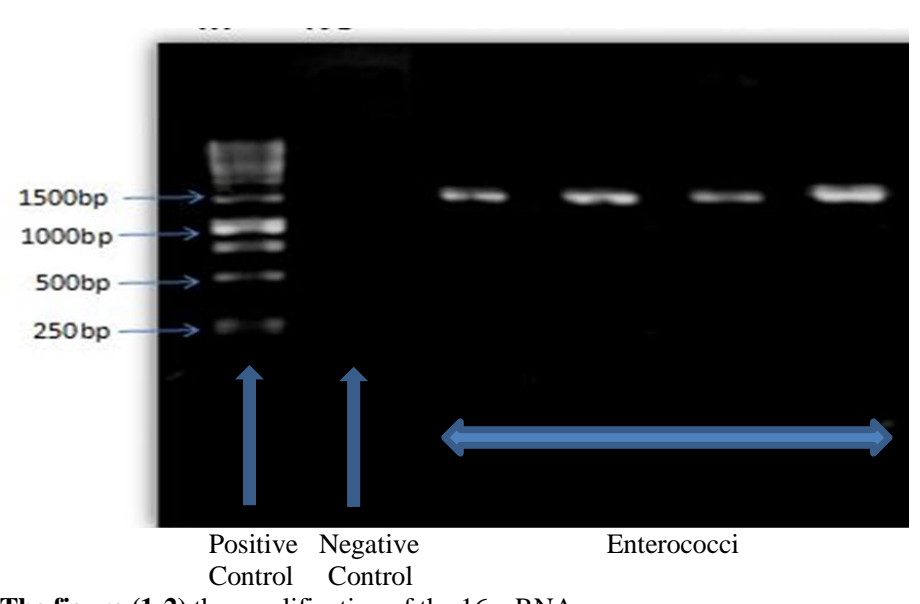

The figure (1-2) the amplification of the 16s rRNA gene

\section{PCR}

The figure above (1-1) shows the amplification of the 16s rRNA gene, in a 1500 bp band, from isolated enterococci. The bands facing it in the next 4 columns are related to the nucleotides of isolated Enterococci and the first column is related to the negative control against which no band is formed. The DNA marker size is $1000 \mathrm{bp}$ in the second row.

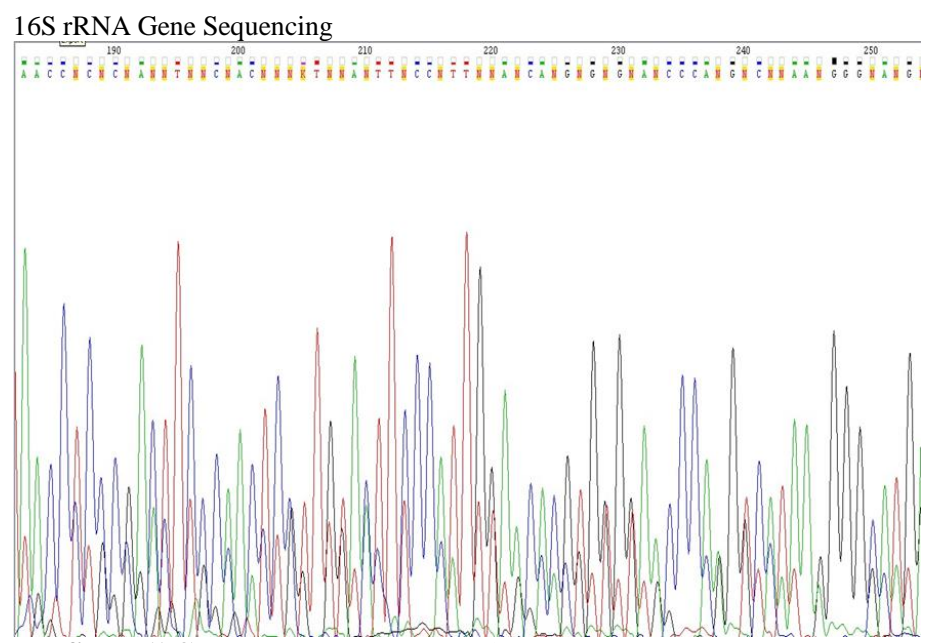

The figure (1-3) 16S rRNA Gene Sequencing

After DNA extraction and PCR 16sr RNA according to Pitchers method by follow, 27F (5'-AGAGTTTGATCCTGG CTCAG-3) and 1492R (5'GGTTACCTTGTTACGACTT-3)

The band was obtained at $1500 \mathrm{bp}$, then the gene product was sent to Macro Gene in South Korea for sequencing, which was obtained as a graph above, and then the primer was compared using primers available at the NCBI site. The result of sequencing was Enterococcus faecium, the similarity was about $98 \%$. This is in line with the results of morphological, biochemical, and glucose fermentation tests.

$16 \mathrm{~S}$ and $23 \mathrm{~S}$ rRNA genes are really important for the identification and detection of many spaces bacteria, but because of the high similarity between their rRNA sequence as $L$. sakei and $L$. curvatus, $16 \mathrm{~S}$ and $23 \mathrm{~S}$ rRNA probes and primers cannot use. Therefore we can use differences in length and sequence of the 16S23S rRNA intergenic spacer regions of the rRNA operon, which can be helpful (Rosqvist et al., 2015).

PCR is a reasonable molecular method for the identification of bacteria without the need for colony isolation. The sensitivity of PCR in foods can be decreased because of some complexity of the food matrix and the presence of many PCR inhibitors.

\section{Fatty acid}

The table (1-5) The FA composition of experimental cheese FATTY ACID PROFILE (Fatty acid composition ( $\mathrm{g} / 100 \mathrm{~g}$ of total fatty acids)

\begin{tabular}{lcc}
\hline Fatty Acid & Result & Reference Range \\
\hline Butyric Acid (C 4:0) & 1.3 & $1 \_4$ \\
Caproic Acid (C 6:0) & 1.19 & $0.8 \_3$ \\
Caprylic Acid (C 8:0) & 1.54 & $0.5 \_1.7$ \\
Capric Acid (C 10:0) & 3.30 & $1.7 \_3.9$ \\
Lauric Acid (C 12:0) & 3.90 & $2.3 \_4.5$ \\
Myristic Acid (C 14:0) & 13.22 & $5.4 \_14.5$ \\
Myristoleic Acid (C 14:1) & 1.7 & $0.5 \_1.7$ \\
Palmitic Acid (C 16:0) & 42.47 & $25 \_41$ \\
Palmitoleic Acid (C 16:1) & 3.49 & $1 \_6$ \\
Stearic Acid (C 18:0) & 4.75 & $6 \_15$ \\
Oleic Acid (C 18:1) & 15.99 & $18 \_33.4$ \\
Oleic Acid (C 18:1) & 2.85 & $1.06 \_3.48$ \\
Linolenic Acid (C 18:2) & 2.39 & $0.9 \_3.7$ \\
Linolenic Acid (C 18:2) & 0.29 & $0.32 \_1.15$ \\
Arachidonic Acid (C 20:0) & 1.53 & $0.8 \_303$ \\
\hline
\end{tabular}

Considering the unsaturated FA of cheese, the concentrations of unsaturated fatty acid were $\% 76.95$, and saturated fatty acid was $\% 23.05$.

The highest concentration of fatty acid was Palmitic Acid (\%42.47), Myristic Acid (\%13.22), and Capric Acid (\%3.30).

In particular, the level of Palmitic Acid (\%42.47) was higher than the Reference Range, which is reasonable because of season and kind of diet. Also, not only the plant family but also the single plant species of the pasture can influence the FA composition (Kliem et al., 2018).

Many studies have reported that, and C12:0, C14:0, and C16:0 in particular, have hypercholesterolemic properties and favor the increase of blood low-density lipoprotein. (Ohlsson et al., 2010). In the present trial, the $\% 60$ concentration of FA is contained C12:0, C14:0, and C16:0.

Fatty acids will vary depending on the type of cheese. Differences in the types of fatty acids in cheese due to the lipolysis process that cheese underwent during ripening. According to this, one of the most important lipolytic factors is the lipoprotein lipase (LPL) derived from the milk and which is inactivated after 
pasteurization. This enzyme preferentially acts towards short-chain fatty acids (McSweeney et al., 2017). Coppa et al .observed that in cheeses ripened, the effect of the cheese-making process had a very small effect on the FA profile. (Coppa et al., 2011).

Considering the categories of FA, because of low level unsaturated fatty acid, Local cheese from Isfahan has high humidity, high resistance toward oxidation. Essential fatty acids of the n-3 and n-6 families are PUFA that are not synthesized by the human organism and must be supplied in the diet. The fatty acids essential for normal human development are linoleic C18:2, $\alpha$-linolenic C18:3 (n-3), eicosapentaenoic C20:5 (n-3; EPA), docosahexaenoic C22:6 (n-3; DHA), $\gamma$-linolenic C18:3 (n-6), and arachidonic C20:4 (n-6) acids (Bodkowski et al., 2017) which, we could find one of them in Isfahan's local cheese.

According to the table, Butyric Acid was the most amount of Reference Range; in other hand it had an important role in flavor and taste of dairy products, which it can be an advantage to our sample.

Chromatogram

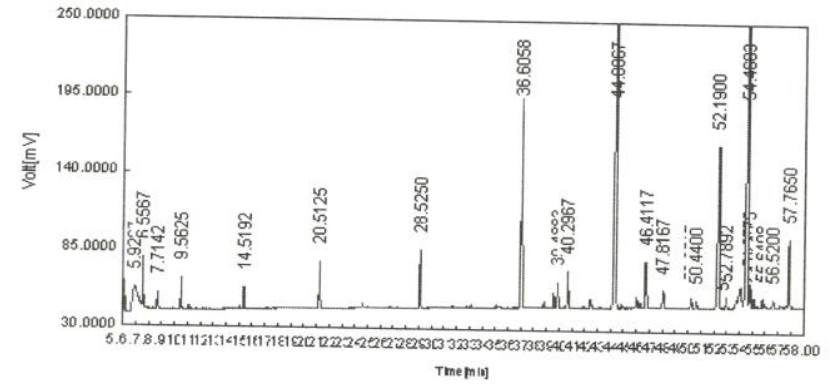

The figure (1-4) Gas Chromatography-Flame Ionization Detector chromatogram of fatty acids methyl esters of total fatty acids extracted from sample of cheese.

Based on the type of cow feed, it can be said that cows fed in pastures have richer milk than cows fed alfalfa. Studies have demonstrated that fatty acids (FA) are useful and effective in the human diet. On the other hands, polyunsaturated fatty acids (PUFA) are able to decrease cardiovascular disease risk and, in animal models, conjugated linoleic acids (CLA) have been shown to be involved in anticarcinogenic, immune-modulatory, and anti-diabetic activities (Suárez-Vega et al., 2019). Fatty acids are components of lipids and have a decisive influence on the quality of dairy products. Fatty acids can exist as free forms and bound forms, such as cholesterol and phospholipids. Fatty acids can be found in many components, also they contain four groups such as saturated, monounsaturated (MUFA), polyunsaturated (PUFA), and trans fats (TFA)( Tokatls et al., 2019). SFAs and TFAs ('bad' FA) have a negative effect on coronary heart disease while MUFAs and PUFAs have a positive role by reducing the risk of coronary heart disease (CHD)( Ruiz-Núñez et al., 2016). World Health Organization (WHO), has introduced the "REPLACE" action package to provide a strategic approach to eliminate industrially-produced TFA from the global food supply chain by 2023 globally, for the investigation purpose of fatty acid composition, GC-MS analysis is used predominately compared to other techniques (LC-MS, GC-FID) due to the advantages in efficiency, selectivity, and cost (Krone et al., 2010). This method included three parts: extraction of the fatty acids from the sample matrix, derivatization of the fatty acids, and GC-MS analysis.

\section{CONCLUSION}

In the present study, the collection samples prepared from local cheese of milk of cows. With this, a total of 83 lactic acid bacteria belonging to the genus Lactobacillus, Lactococcus, Leuconostoc, Streptococcus, Enterococcus, and Pediococcus were identified from one cheese sample. The results obtained from the present study demonstrated that there is a diversity of lactic acid bacteria in local cheese. The presence of LAB in milk and milk products enhances the bioavailability of nutrients and act as a preservative. From this study, we can conclude that cheese is a rich source of LAB. In addition, it was proven that cheese contained both homo-fermentative and hetero-fermentative lactic acid bacteria. This local cheese could serve as a source for beneficial lactic acid bacteria in future researches. Further studies will be done on the characterization, identification of species level, and their probiotic potential. Isfahan local cheese is a major source of dietary fatty acids. The study demonstrated that Isfahan local cheese is a rich source of saturated fatty acids that has a detrimental effect on health but it is also observed that it is also a major source of essential fatty acids that have a beneficial impact on health. In any case, attempts to improve the resolution of as many as possible FA in the GC analysis have been constant during the last decades. in many studies, the analysis of milk fat means identifying the Cis and Trans, due to the effects of isomers of c18:1 and CLA, on human health. Based on results only t11-C18:1 is associated with human health. (Valdivielso et al., 2017). Lavasani and Ehsani (2012) reported butyric acid as one of the most important fatty acid in probiotic Lighvan cheese inoculated with Bifid bacterium lactic. Microorganisms with lipolysis activity, such as enterococci and yeasts identifying in local Lighvan cheese (Kafili et al., 2009), and lipoprotein lipase played a key role in lipolysis. The results demonstrated, cheese contains other fatty acids, e.g. conjugated linoleic acid and oleic acid, which have the potential to improve long-term health, due to the Properties of this acid including antioxidant, anti-cancer, anti-hypertensive, anti-cholesterol and anti-diabetic, cardiovascular problems. As cheese fat is one of the most complex natural fats, due to its FA composition, its accurate analysis is also one of the most complex and challenging tasks for any food analyst. For decades, it has been a field for constant advance and improvement. New chromatographic arrangements in multiple dimensions, long GC capillary columns, TLC, SPE, and HPLC methods for improved fractionations, mass spectrometers to identify minor FA make it possible to detect and quantify the vast majority of the FA present in milk. However, there is still scope either to refine existing methods or to improve techniques that could accelerate and makes shorten the analysis. In any case, the current options are numerous and varied and the analyst must choose an adequate methodology according to the objectives pursued.

Traditional fermented dairy consumption dates back thousands of years around the world. Over the years, a number of lactic acid bacteria were selected and passed on to the next generation. in order to be beneficial LAB, there has been increasing interest in the exploitation of $\mathrm{LAB}$ in traditional fermented dairy products and biodiversity. By pure culture method and gene sequencing technology, 9 LAB strains were isolated and identified.

Acknowledgments: The authors are grateful to the Dean of Graduate Studies, North Tehran Branch, Islamic Azad University, Tehran, Iran, for providing assistance with the experiments, and the valuable discussions.

\section{REFERENCE}

Haytowitz, D. B., \& Pehrsson, P. R. (2018). USDA's National Food and Nutrient Analysis Program (NFNAP) produces high-quality data for USDA food composition databases: Two decades of collaboration. Food Chemistry, 238, 134-138. doi:10.1016/j.foodchem.2016.11.082

Delavenne, E., Mounier, J., Déniel, F., Barbier, G., \& Le Blay, G. (2012). Biodiversity of antifungal lactic acid bacteria isolated from raw milk samples from cow, ewe and goat over one-year period. International Journal of Food Microbiology, 155(3), 185-190. doi:10.1016/j.ijfoodmicro.2012.02.003

Wouters, J. T. ., Ayad, E. H. ., Hugenholtz, J., \& Smit, G. (2002). Microbes from raw milk for fermented dairy products. International Dairy Journal, 12(2-3), 91109. doi:10.1016/s0958-6946(01)00151-0

Elyass, M. E., Shigidi, M. T., Attitalla, I. H., \& Mahdi, A. A. (2017). Characterization and Optimization of Bacteriocin from \&lt;i\&gt;Lactobacillus plantarum\&lt;/i\&gt; Isolated from Fermented Beef (Shermout). Open Journal of Applied Sciences, 07(03), 83-97. doi:10.4236/ojapps.2017.73008

Hayek, S. A., Gyawali, R., Aljaloud, S. O., Krastanov, A., \& Ibrahim, S. A. (2019). Cultivation media for lactic acid bacteria used in dairy products. Journal of Dairy Research, 86(4), 490-502. doi:10.1017/s002202991900075x

Sharma, A., Lavania, M., Singh, R., \& Lal, B. (2020). Identification and probiotic potential of lactic acid bacteria from camel milk. Saudi Journal of Biological Sciences. doi:10.1016/j.sjbs.2020.11.062

Steele, J., Broadbent, J., \& Kok, J. (2013). Perspectives on the contribution of lactic acid bacteria to cheese flavor development. Current Opinion in Biotechnology, 24(2), 135-141. doi:10.1016/j.copbio.2012.12.001

Vázquez-Velázquez, R., Salvador-Figueroa, M., Adriano-Anaya, L., DeGyvesCórdova, G., \& Vázquez-Ovando, A. (2018). Use of starter culture of native lactic acid bacteria for producing an artisanal Mexican cheese safe and sensory acceptable. CyTA - Journal of Food, 16(1), 460-468. doi:10.1080/19476337.2017.1420694

Duan, Y., Tan, Z., Wang, Y., Li, Z., Li, Z., Qin, G., Cai, Y. (2008). Identification and characterization of lactic acid bacteria isolated from Tibetan 
Qula cheese. The Journal of General and Applied Microbiology, 54(1), 51-60. doi:10.2323/jgam.54.51

Weinberg, Z. G., Shatz, O., Chen, Y., Yosef, E., Nikbahat, M., Ben-Ghedalia, D., \& Miron, J. (2007). Effect of Lactic Acid Bacteria Inoculants on In Vitro Digestibility of Wheat and Corn Silages. Journal of Dairy Science, 90(10), 47544762. doi:10.3168/jds.2007-0176

Antibacterial activity of lactic acid bacteria isolated from milk and traditional fermented dairy products of south Algeria against multidrug resistance pathogenic bacteria. (2020). South Asian Journal of Experimental Biology, (10(5)). doi:10.38150/sajeb.10(5).p322-331

Ghalouni, E., Hassaine, O., \& Karam, N.-E. (2018). Phenotypic Identification and Technological Characterization of Lactic Acid Bacteria Isolated from L'ben, An Algerian Traditional Fermented Cow Milk. Journal of Pure and Applied Microbiology, 12(2), 521-532. doi:10.22207/jpam.12.2.11

Marcelino, J. (2013). Lactic Acid Bacteria as Starter-Cultures for Cheese Processing: Past, Present and Future Developments. Lactic Acid Bacteria - R \& D for Food, Health and Livestock Purposes. doi:10.5772/55937

Chen, H., \& Narbad, A. (2018). Proteins and Exopolysaccharides of Lactic Acid Bacteria. Lactic Acid Bacteria in Foodborne Hazards Reduction, 51-85. doi:10.1007/978-981-13-1559-6 3

SRIPHOCHANART, W., \& SKOLPAP, W. (2010). THE USE OF SELECTED LACTIC ACID BACTERIA STARTER CULTURES FOR IMPROVED THAI SAUSAGE FERMENTATION. Journal of Food Processing and Preservation, 35(3), 291-298. doi:10.1111/j.1745-

Aymerich, T., Martín, B., Garriga, M., \& Hugas, M. (2005). Microbial Quality and Direct PCR Identification of Lactic Acid Bacteria and Nonpathogenic Staphylococci from Artisanal Low-Acid Sausages. Applied and Environmental Microbiology, 71(3), 1674-1674. doi:10.1128/aem.71.3.1674.2005

Karakas-Sen, A., \& Karakas, E. (2018). Isolation, identification and technological properties of lactic acid bacteria from raw cow milk. Bioscience Journal, 985-999. doi:10.14393/bj-v34n2a2018-34517

Ho, J. C. K., \& Yin Sze, L. (2018). Isolation, identification and characterization of enzyme-producing lactic acid bacteria from traditional fermented foods. Bioscience Horizons: The International Journal of Student Research, 11. doi:10.1093/biohorizons/hzy004

Abdullah, S. A., \& Osman, M. M. (2010). Isolation and Identification of Lactic Acid Bacteria from Raw Cow Milk, White Cheese and Rob in Sudan. Pakistan Journal of Nutrition, 9(12), 1203-1206. doi:10.3923/pjn.2010.1203.1206

Yu, J., Wang, H. M., Zha, M. S., Qing, Y. T., Bai, N., Ren, Y., ... Zhang, H. P. (2015). Molecular identification and quantification of lactic acid bacteria in traditional fermented dairy foods of Russia. Journal of Dairy Science, 98(8), 5143-5154. doi:10.3168/jds.2015-9460

Liu, W., Pang, H., Zhang, H., \& Cai, Y. (2014). Biodiversity of Lactic Acid Bacteria. Lactic Acid Bacteria, 103-203. doi:10.1007/978-94-017-8841-0 2

Fernandez, E. M., Valenti, V., Rockel, C., Hermann, C., Pot, B., Boneca, I. G., \& Grangette, C. (2011). Anti-inflammatory capacity of selected lactobacilli in experimental colitis is driven by NOD2-mediated recognition of a specific peptidoglycan-derived muropeptide. Gut, 60(8), 1050-1059. doi:10.1136/gut.2010.232918

Acharya, M. R., \& Mistry, V. V. (2004). Comparison of Effect of VacuumCondensed and Ultrafiltered Milk on Cheddar Cheese. Journal of Dairy Science, 87(12), 4004-4012. doi:10.3168/jds.s0022-0302(04)73541-9

Rosqvist, F., Smedman, A., Lindmark-Månsson, H., Paulsson, M., Petrus, P., Straniero, S., ... Risérus, U. (2015). Potential role of milk fat globule membrane in modulating plasma lipoproteins, gene expression, and cholesterol metabolism in humans: a randomized study1. The American Journal of Clinical Nutrition, 102(1), 20-30. doi:10.3945/ajen.115.107045

Kliem, K. E., Thomson, A. L., Crompton, L. A., \& Givens, D. I. (2018). Effect of selected plant species within biodiverse pasture on in vitro fatty acid biohydrogenation and tissue fatty acid composition of lamb. Animal, 12(11), 2415-2423. doi:10.1017/s1751731118000265

Ohlsson, L. (2010). Dairy products and plasma cholesterol levels. Food \& Nutrition Research, 54(1), 5124. doi:10.3402/fnr.v54i0.5124

McSweeney, P. L. H. (2017). Biochemistry of Cheese Ripening: Introduction and Overview. Cheese, 379-387. doi:10.1016/b978-0-12-417012-4.00014-4

Coppa, M., Ferlay, A., Monsallier, F., Verdier-Metz, I., Pradel, P., Didienne, R., ... Martin, B. (2011). Milk fatty acid composition and cheese texture and appearance from cows fed hay or different grazing systems on upland pastures. Journal of Dairy Science, 94(3), 1132-1145. doi:10.3168/jds.2010-3510
Bodkowski, R., Czyż, K., Kupczyński, R., Patkowska-Sokoła, B., Nowakowski, P., \& Wiliczkiewicz, A. (2016). Lipid complex effect on fatty acid profile and chemical composition of cow milk and cheese. Journal of Dairy Science, 99(1), 57-67. doi:10.3168/jds.2015-9321

Conjugated linoleic acid (CLA)-induced milk fat depression: application of RNA-Seq technology to elucidate mammary gene regulation in dairy ewes

Suárez-Vega, A., Gutiérrez-Gil, B., Toral, P. G., Hervás, G., Arranz, J. J., \& Frutos, P. (2019). Conjugated linoleic acid (CLA)-induced milk fat depression: application of RNA-Seq technology to elucidate mammary gene regulation in dairy ewes. Scientific Reports, 9(1). doi:10.1038/s41598-019-40881-3

Animal and vegetable fats and oils. Gas chromatography of fatty acid methyl esters. (n.d.). doi:10.3403/30190500u

Tokatlı, M., Gülgör, G., Bağder Elmacı, S., Arslankoz İşleyen, N., \& Özçelik, F. (2015). In VitroProperties of Potential Probiotic Indigenous Lactic Acid Bacteria Originating from Traditional Pickles. BioMed Research International, 2015, 1-8. doi:10.1155/2015/315819

Ruiz-Núñez, B., Dijck-Brouwer, D. A. J., \& Muskiet, F. A. J. (2016). The relation of saturated fatty acids with low-grade inflammation and cardiovascular disease. The Journal of Nutritional Biochemistry, 36, 1-20. doi:10.1016/j.jnutbio.2015.12.007

Krone, N., Hughes, B. A., Lavery, G. G., Stewart, P. M., Arlt, W., \& Shackleton, C. H. L. (2010). Gas chromatography/mass spectrometry (GC/MS) remains a preeminent discovery tool in clinical steroid investigations even in the era of fast liquid chromatography tandem mass spectrometry (LC/MS/MS). The Journal of Steroid Biochemistry and Molecular Biology, 121(3-5), 496-504. doi:10.1016/j.jsbmb.2010.04.010

Valdivielso, I., de Renobales, M., Aldai, N., \& Barron, L. J. R. (2017). Changes in terpenoid composition of milk and cheese from commercial sheep flocks associated with seasonal feeding regimens throughout lactation. Journal of Dairy Science, 100(1), 96-105. doi:10.3168/jds.2016-11761

Lavasani, R. S., \& Ehsani, M. R. (2012). Effect of Bifidobacterium Lactis on Free Fatty Acids of Lighvan Cheese during Ripening. Journal of Medical and Bioengineering, 1(1), 4-6. doi:10.12720/jomb.1.1.4-6

Kafili, T., Razavi, S. H., Djomeh, Z. E., Naghavi, M. R., Álvarez-Martín, P., \& Mayo, B. (2009). Microbial characterization of Iranian traditional Lighvan cheese over manufacturing and ripening via culturing and PCR-DGGE analysis: identification and typing of dominant lactobacilli. European Food Research and Technology, 229(1), 83-92. doi:10.1007/s00217-009-1028-x 